\title{
MENINGKATKAN KEDISIPLINAN GURU DAN KINERJA GURU PADA SD NEGERO 007 TELUK SEBONG KECAMATAN TELUK SEBONG
}

\author{
Elsinar Girsang \\ Kepala SDN 007 Teluk Sebong \\ Email: elsinargirsang1@gmail.com
}

\begin{abstract}
Abstrak
Tujuan penulisan ini untuk melihat hubungan antara kedisiplinan guru dengan kinerja guru dalam melaksanakan tugas sebagai pendidik agar tujuan pendidikan dapat tercapai dengan baik. Penulisan ini dilakukan di lingkungan Dinas Pendidikan SD Negeri 007 Teluk Sebong, Berdasarkan uraian yang telah penulis paparkan pada analisa kedisiplinan guru dalam upaya meningkatkan kinerja guru maka dapat disimpulkan, sebagai berikut: (a) Patuh dan taat pada ketentuan bersama yang meliputi: datang tepat pada waktunya, mengikuti kegiatan-kegiatan sekolah dll, melaksanakan pembelajaran tepat waktu, mengunakan pakaian dan atribut sesuai ketentuan yang berlaku, dan guru menyusun perangkat tepat pada waktunya; (b) Kemampuan mengendalikan diri yang meliputi: guru dalam menjalankan tugas selalu mengedepankan etika; (c) Patuh terhadap tugas pokok guru yang meliputi: guru menyusun perangkat kerja, menyiapkan media pembelajaran, melakukan evaluasi dan pengayaan, serta memberikan penilaian sikap dan perilaku terhadap siswa; (d) Menciptakan suasana harmonis terhadap rekan kerja dan atasan yang meliputi: guru memiliki rasa empati terhadap rekan kerja didalam maupun diluar lingkungan kerja, guru menyelesaikan persoalan secara demokrasi dan kekeluargaan; (e) Menciptakan sikap kreatif dan inovasi yang meliputi: Guru memahami IT, memiliki wawasan kekinian, memiliki sikap tanggap lingkungan, dan mengikuti pelatihan penyetaraan profesi; (f) Memiliki loyalitas terhadap profesinya sebagai guru.
\end{abstract}

\section{Kata Kunci: Kedisiplinan, Kinerja, Guru SD Negeri 007 Teluk Sebong.}

\section{PENDAHULUAN}

Sekolah sebagai lembaga pendidikan formal berfungsi untuk memberikan pengetahuan dan keterampilan, serta membentuk sikap dan kepribadian siswa. Guru sebagai pelaku untuk membentuk sikap dan kepribadian siswa harus menyusun materi yang diberikan, hendaknya dirumuskan sedemikian rupa dalam bentuk program - program pendidikan sehingga kondusif untuk mencapai tujuan pendidikan yang diselenggarakan sekolah. Objek pendidikan adalah siswa dan tugas guru adalah mempengaruhi pembentukan pribadi peserta didik, semua itu dapat tercapai dengan adanya proses belajar mengajar

Guru sebagai tenaga pendidik merupakan ujung tombak keberhasilan anak didik di sekolah, namun yang dirsakan selama ini masih belum sesuai dengan tuntutan dan kebutuhan sesuai dengan perkembangan zaman. Untuk itu perlu adanya upaya pengembangan potensi yang dimiliki guru sebagai pendidik di sekolah.

Peran guru sebagai pendidik lebih berorientasi sebagai pemimpin kegiatan proses belajar mengajar dimana guru harus membuat perencanaan, melaksanakan perencanaan, mengorganisisr dan mengawasi kegiatan proses belajar mengajar itu. Guru harus dapat mengelola kelas dengan baik, menggunakan metode dan model pembelajaran yang tepat sesuai dengan karekteristik dan kemampuan siswa serta lingkungan dan kondisi yang ada pada saat proses belajar mengajar berlansung. Supaya kegiatan belajar mengajar berjalan kondusif bantuan guru terhadap siswa berupa bimbingan individu ataupun kelompok dalam proses belajar mengajar merupakan bagian yang sangat penting dari tugas guru sebagai pemimpin dalam proses belajar mengajar di kelas.

Guru dalam mengajar siswa, harus dapat menunjukan sikap yang baik karena tindak tanduk guru akan dicontoh oleh siswa dan guru 
harus menguasi ilmu pengetahuan sesuai dengan mata pelajaran yang diajarkannya. Karena mengajar adalah suatu pekerjaan atau potensi yang sangat kompleks yang membutuhkan penguasaan ilmu, seni dan keterampilan dalam mengajar yang harus dikuasai guru agar ia dapat melaksanakan tugasnya dengan baik. Untuk tercapainya hasil belajar yang optimal dipengaruhi oleh beberapa faktor, diantaranya adalah faktor kedisiplinan dan kepribadian guru yang dapat meningipkatkan kinerja guru dalam mengajar sehingga hasil belajar akan dapat ditingkatkan.

Kedisiplinan guru dapat diwujudkan melalui aktivitas yang berhubungan dengan pekerjaannya atau dengan kata lain bahwa kedisiplinan guru dapat direalisasikan melalui aktivitas yang berhubungan dengan kegiatan belajar mengajar. Hasil penelitian ini diharapkan dapat memberi manfaat yang berarti bagi sekolah dalam mencapai tujuan pendidikan menuju pendidikan yang berkualitas. Keberhasilan pendidikan dipengaruhi oleh berbagai faktor pendukung sarana dan prasarana yang memadai sesuai dengan perkembangan zaman sehingga siswa dapat belajar sebaik-baiknya.

Secara khusus penulisan ini dapat bermanfaat bagi pihak-pihak antara lain: (1) Pengambil kebijaksanaan pendidikan tinggi terutama untuk memecahkan masalah pendidikan di Indonesia; (2) Perencana pembangunan dibidang pendidikan; (3) Pengambil keputusan sebagai masukan yang berkaitan dengan pembangunan dalam bidang pendidikan; (4) Perencanaan, pengelolaan dan pelaksanaan pendidikan di lingkungan SD Negeri 007 Teluk Sebong; (5) Seluruh majelis guru dan staf tata usaha di SD Negeri 007 Teluk Sebong; (6) Bagi penulis dapat membuka ruang untuk penulisan selanjutnya.

\section{Hakikat Kinerja Guru}

Pengertian kinerja guru tidak dapat dipisahkan dari apa yang terjadi dalam kegiatan kerja, baik di dalam kantor, maupun diluar kantor. Apa yang dialami guru dalam proses pengetahuan kemampuannya merupakan apa yang diperolehnya. Pengetahuan itu dipengaruhi pula oleh beberapa faktor seperti: kualitas kinerja penyelenggara pendidikan serta karakteristik kinerja penyelenggara pendidikan merupakan pencerminan profesionalisme guru.

Sekolah adalah tempat penyelenggaraan pendidikan yang merupakan organisasi formal terdiri dari beberpa komponen-komponen yang melaksanakan tugas sesuai dengan fungsinya masing-masing dan saling bekerjasama untuk mencapai tujuan tertentu. Robbins dalam hubungan ini mengemukakan: sebuah organisasi adalah suatu kesung guhan sosial yang dikoordinasikan secara sadar dengan batasan yang dapat diidentifikasi secara relative dan yang berfungsi sebagai dasar yang secara relative berlanngsung terus menerus mencapai tujuan.

Lebih lanjut Reksohadiprodjo mengemukakan hakekat suatu organisasi (perusahaan) adalah adanya orang-orang yang usahanya harus dikoordinasikan, tersusun dari sejumlah subsistem yang saling berhubungan dan saling tergantung, bekerja bersama atas dasar pembagian kerja, peran dan wewenang serta mempunyai tujuan tertentu yang hendak dicapai. Dari jabaran di atas memperlihatkan bahwa organisasi bukan sekedar kumpulan orang dan bukan pula sekedar pembagian kerja sebab pembagian kerja hanyalah salah satu azas organisasi tetapi didalamnya terdapat keterikatan individu dan saling mempengaruhi. Sutarto dalam hal ini mengemukakan bahwa organisasi adalah sistem saling pengaruh antar orang dalam kelompok yang bekerjasama untuk mencapai tujuan tertentu.

Bertitik tolak dari kutipan tersebut dapat dikatakan bahwa dalam organisasi terdapat tiga unsur pokok yaitu: (1) adanya tujuan yang akan dicapai, (2) adanya pembagian tugas antar kelompok orang, (3) adanya kerjasama antar sesama anggota. Penyelenggara pendidikan sebagai salah satu organisasi didalamnya terdapat kerjasama sekelompok orang (Kepala sekolah penyelenggara pendidikan) yang secara bersamasama ingin mencapai tujuan dengan adanya kerjasama antar sesama anggota, yang secara bersama- samaingin mencapai tujuan yang telah ditetapkan sebelumnya. Semua komponen yang ada dalam penyelenggara pendidikan.

Pendidikan merupakan bagian yang integral, artinya walaupun dalam kegiatannya melakukan pekerjaan sesuai dengan fungsi masing - masing tetapi secara keseluruhan pekerjaan mereka disahkan pada tujuan organisasi. Untuk mencapai tujuan dimaksud diperlukan iklim kerja yang kondusif memungkinkan semua komponen sekolah dapat berinteraksi dan bekerjasama dalam suasana yang menyenangkan. Iklim kerja biasanya bersifat dinamik, hal ini berarti iklim kerja dapat berubah sesuai dengan kondisi lingkungan yang mempengaruhinya. Oleh karena 
itu iklim kerja perlu diperhatikan agar penyelenggaraan pendidikan tetap efektif mencapai tujuan.

Iklim kerja adalah situasi atau fenomena yang dialami atau dirasakan setiap orang dalam berbagai kegiatan. Apabila iklim kerja dirasakan sungguh menyenangkan, maka perilaku organisasi akan efektif mencapai tujuan. Steers mengemukakan iklim yang timbul dalam organisasi merupakan faktor yang menentukan perilaku pekerja. Bilamana iklim bermanfaat bagi kebutuhan individu (misalnya, mempertahankan kepentingan pekerja dan beroreantasi pada prestasi), maka kita dapat mengharapkan tingkat perilaku kearah tujuan yang tinggi.

Kutipan tersebut memperjelas bahwa iklim kerja yang kondusif dapat meningkatkan semangat kerja penyelenggara pendidikan, yang sekaligus dapat meningkatkan kreativitas, memotivasi pengembangan karier sesuai dengan minat, kebutuhan dan kemampuan Kepala sekolah penyelenggara diklat.

Sebaliknya iklim kerja yang kurang menyenangkan akan menghambat tumbuh kembangnya kreativitas penyelenggara pendidik Iklim kerja merupakan perpaduan antara beberapa elemen yang secara keseluruhan diterima oleh komponen penyelenggara diklat sebagai norma - norma dan sistem sosial. Owens dalam hal ini mengemukakan sebagai berikut: sekolah merupakan variabel - variabel yang komposite seperti yang ditentukan oleh anggota grup tersebut, faktor ini mungkin secara luas diterima sebagai norma - norma dalam sistem sosial dan pengharapan yang dipegang oleh anggota yang berbeda seperti persieved untuk anggota dari grup itu dan dikomunikasikan pada anggota grup tersebut.

Kepala sekolah penyelenggara pendidikan sebagai penanggung jawab pembinaan penyelenggara pendidikan dan pengembangan penyelenggara diklat memegang peranan kunci dalam upaya menciptakan iklim kerja yang kondusif dalam penyelenggaraan pendidikan yang memungkinkan kreativitas guru dapat tumbuh dan berkembang. Pidarta mengemukakan iklim dan lingkungan belajar mempunyai pengaruh yang cukup besar terhadap keberhasilan penyelenggaraan diklat sebab iklim dan lingkungan yang kondusif memberikan perasaan nyaman dan bebas baik bagi pihak penyelenggara diklat yang bekerja maupun para unsr penyelenggara diklat, hal ini memungkinkan prestasi kerja mereka semakin meningkat. Untuk menciptakan iklim kerja yang kondusif banyak faktor yang berpengaruh yang perlu diperhatikan.

Menurut pidarta terdapat lima faktor yang mempengaruhi iklim kerja yang kondusif, yaitu: (1) penempatan personalia, (2) pembinaan antar hubungan dan komunikasi, (3) dinamisasi dan penyelesaian konflik, (4) pemanfaatan informasi, dan (5) peningkatan lingkungan kerja Proses komunikasi merupakan salah satu faktor yang esensial untuk terciptanya iklim kerja yang kondusif. Secara kodrat manusia satu sama lain saling berhubungan dan membutuhkan, dimana hal ini dapat terwujud melalui proses komunikasi.

Proses komunikasi berfungsi mengikat masing - masing sekolah menjadi satu bagian yang integeral. Ikatan yang terbentuk karena komunikasi yang harmonis dan lancar dapat mendorong semangat kerjasama dan menumbuhkan sikap peduli dengan lingkungan kerja yang semuanya itu mempengaruhi iklim kerja. Coolamleys dalam hubungan ini mengemukakan bahwa: tanpa komunikasi pikiran tidak dapat mengembanagkan sikap alami manusia yang asli tetapi dalam keadaan yang tidak normal dan sikap yang lebih kasar. Kutipan ini mengisyaratkan supaya setiap komponen penyelenggara diklat membuat suatu sistem komunikasi kerjasama yang harmonis sehingga tercipta iklim kerja yang kondusif. Penyelenggara pendidikan yang menggunakan komunikasi terbuka dan persuasif dapat merangsang semangat kerja sehingga mereka akan lebih antusias melaksanakan tugas. Sebaliknya komunikasi dan kerjasama yang kurang harmonis antara semua komponen penyelenggara diklat terutama antara Kepala sekolah penyelenggara diklat akan tercermin dari perilaku dimana mereka bekerja seolah -olah terpaksa.

Apabila Kepala sekolah yang mengeluarkan kata-kata ancaman akibatnya penyelenggara diklat dianggap sebagai kegiatan rutinitas dan membosankan sehingga sekalipun mereka melakukan tugas, hal tersebut hanya memenuhi kewajiban. Dengan demikian hendaknya Kepala sekolah dan penyelenggara diklat bekerja sama memelihara faktor-faktor atau dimensi yang berpengaruh terhadap iklim kerja. Owens menyebutkan empat dimensi pokok yang berpengaruh terhadap iklim penyelenggaraan diklat yaitu: (1) ekologi, (2) milieu, (3) sistem sosial, dan (4) budaya. Halpin dan Croft dalam Hoy dan Miskel mengemukakan faktor - faktor yang menentukan iklim kerja sebagai berikut: (1) rintangan, (2) keintiman, (3) pelepasan, (4) 
semangat, (5) penekanan pada produksi, (6) sikap menyendiri, (7) dorongan, dan (8) pertimbangan. Berdasarkan faktor - faktor tersebut halpin dan Croft mengemukakan ada dua bentuk iklim sekolah yaitu: terbuka dan tertutup.

Pada iklim sekolah terbuka aspek semangat guru sangat tinggi, demikian pula dengan aspek pertimbangan dan dorongan yang diberikan Kepala sekolah dan rekan sejawat ternyata cukup besar sehingga mampu mendorong guru untuk terus berkreasi.

Aspek yang mempunyai intensitas rendah adalah aspek rintangan atau mengelak, tidak terikat, menekankan pada produksi dan sikap menyendiri. Dilain pihak aspek keintiman tampak mempunyai intensitas yang sedang. Pada iklim sekolah tertutup semangat guru adalah rendah demikian juga dengan aspek pertimbangan dan dorongan yang diberikan Kepala sekolah sekolah dan rekan sejawat. Pada aspek rintangan tidak terikat menekankan produksi dan sikap menyendiri termasuk katagori baik dan cukup. Aspek keintiman termasuk intensitas yang sedang atau sama dengan iklim sekolah terbuka.

Sehubungan dengan jenis - jenis iklim kerja dan faktor - faktor yang mempengaruhi Croft dalam Burhanuddin mengemukakan bahwa iklim kerja terdiri dari beberapa golongan sebagai berikut: (1) iklim terbuka, (2) iklim bebas, (3) iklim terkontrol, (4) iklim yang familiar atau kekeluargaan, (5) iklim keayahan, dan (6) iklim tertutup. Walaupun para ilmuwan memberi pandangan yang berbeda - beda tentang dimensi atau karakter iklim kerja disekolah namun dari beberapa teori yang ada tidaklah terdapat perbedaan yang berarti. Satu hal yang perlu menjadi perhatian adalah bahwa semua komponen yang ada dalam sekolah terutama Kepala sekolah wajib menciptakan dan memelihara iklim kerja yang kondusif karena dengan adanya iklim yang menyenangkan guru akan lebih bersemanagat melaksanakan tugasnya dan tujuan sekolah akan tercapai secara optimal. Steers mengidentifikasi 10 dimensi iklim kerja pada tingkat organisasi secara keseluruhan, dimensi - dimensi dimaksud adalah: (1) struktur tugas, (2) hubungan imbalan hukum, (3) sentralisasi keputusan, (4) tekanan pada prestasi, (5) tekanan pada latihan dan pengembangan, (6) keamanan versus resiko, (7) keterbukaan versus ketertutupan, (8) status dan semangat, (9) pengakuan dan umpan balik, (10) kompetensi dan keluwesan organisasi secara umum. Lebih lanjut
Cooke and Slack mengemukakan 4 dimensi iklim yang ada dalam organisasi yaitu: (1) hak individu, (2) tingkat susunan yang menentukan, (3) orientasi hadiah, dan (4) tingkat dukungan untuk perhatian dan penghargaan.

Dari beberapa teori yang ada, tentang faktor - faktor yang mempengaruhi iklim kerja tampaknya masing - masing ada perbedaan. Tetapi disisi lain terdapat persamaan persepsi terutama dalam hal penekanan pada pendekatan suasana psikologis dimana masing - masing faktor saling melengkapi antara satu dengan yang lainnya. Kesimpulan yang dapat di tarik dari uraian diatas adalah bahwa iklim kerja di sekolah merupakan suasana psikologis atau fenomena yang dirasakan oleh semua komponen di dalam kegiatannya sehari - hari. Iklim kerja sangat berpengaruh terhadap kinerja guru sehingga semua komponen sekolah terutama Kepala sekolah sekolah diharapkan mampu menciptakan dan memelihara iklim kerja yang kondusif di sekolah.

Kinerja guru dapat dilihat dari beberapa dimensi antara lain, keterbukaan komunikasi antara sesama komponen sekolah, kerjasama yang saling menguntungkan, gaya kepemimpinan Kepala sekolah sekolah dan kepuasan guru.

Dari beberapa teori yang sudah diuraikan tentang kinerja guru di sekolah maka ada beberapa langkah yang harus dilakukan yaitu: (1) Kesediaan kerjasama antar sesama guru dan antar Kepala sekolah sekolah dengan guru, (2) keterbukaan dalam komunikasi, (3) rasa persatuan dan kesatuan, (4) kepuasan kerja. Bilamana hal tersebut dapat berjalan dengan kesadaran yang tulus, maka peningkatan kinerja guru akan lebih optimal.

Untuk mencapai tujuan organisasi, diperlukan sumber daya manusia yang penuh dengan tanggungjawab, kesetiaan, dan ketaatan pada induk organisasi serta sadar untuk mengerjakan sesuatu pekerjaan. Untuk menghasilkan kinerja yang maksimal, disiplin kerja merupakan ujung tombak dalam pencapaian tujuan.

Suatu hal yang sangat penting dalam suatu organsasi adalah disiplin, yang berasal dari bahasa Inggris "dicipline" yang berarti tata tertib. Tata tertib merupakan syarat pertama dalam suatu organisasi, karena organisasi merupakan alat untuk mencapai tujuan. Disiplin juga merupakan alat agar anggota dalam organisasi bersikap dan bertingkah laku mematuhi peraturan-peraturan yang berlaku dalam organisasi. 
Disamping itu dalam organisasi selalu terdapat orang-orang yang tidak mematuhi tata tertib yang sudah dibuat secara bersama atau norma-norma yang sudah ada. Kedisiplinan diartikan sebagai upaya untuk mencegah terjadinya pelanggaran atas ketentuan atau peraturan yang telah disepakati bersama dalam melaksanakan kegiatan kerja. Pemberian sanksi perlu kepada seseorang atau kelompok orang yang melakukan pelanggaran, agar pelanggaran yang sama tidak terjadi pada orang lainnya. Disiplin kerja yang berdaya guna diartikan untuk menumbuhkan dinamika kerja, supaya lebih kreatif dan inovatif.

Masalah disiplin kerja merupakan indikasi penyimpangan prilaku dikalangan penyelenggara pendidikan, misalnya malas dan datang selalu terlambat, mengganggu orang lain yang sedang bekerja, membuat keributan, membolos pada waktu kerja, pulang sebelum waktunya dan melakukan tindakan-tindakan agresif. Dikatakan prilaku yang menyimpang karena terjadi pelanggaran nilai, norma, dan ketentuan yang berlaku, baik yang ditetapkan oleh Kepala sekolah maupun yang ditetapkan oleh peraturan sendiri.

Masalah perilaku tidak berdisiplin ini disebabkan oleh faktor internal dan eksternal, faktor internal adalah yang bersumber dari dalam diri sendiri, yang disebabkan oleh imlikasi perkembangannya sendiri, misalnya kebutuhan tak terpuaskan, kurang cerdas, kurang kuat ingatananya, atau karena energi yang berlebihan. Faktor eksternal adalah yang bersumber pada pengaruh-pengaruh luar seperti tugas yang sulit dipahami, cara kerja kurang efektif, kurang menarik minat, sikap penyelenggara pendidikan dan latihan yang menekan, sikap yang tidak adil, bahasa penyelenggara pendidkan dan latihan yang kurang dipahami atau sulit ditangkap, alat kerja yang kurang lengkap. Suasana dan masalah disiplin kerja ini pada gilirannya menimbulkan akibat-akibat yang tidak menguntungkan, baik bagi pribadi ataupun bagi pelaksanaan kerja di pendidikan dan latihan.

Bagi peserta justru menimbulkan perilaku yang merugikan dan tak bertanggung jawab, sehingga mempengaruhi perkembangan pribadi seseorang, dan bagi pelaksana pendidikan akan menyebabkan suasana lingkungan kerja menjadi kurang menarik dan menumbuhkan gangguan kerja, sehingga akan mempengaruhi keberhasilan dan kemajuan pegawai serta menumbuhkan perilaku yang deskriptif lainnya. Disiplin kerja adalah suatu kondisi dimana penyelenggara pendidikan menggunakan waktu mereka dalam cara-cara penyelenggaraan pendidikan, dimana yang tidak dapat membuat kondisi ini maka dapat menjadi penyelenggara pendidikan yang akhirnya akan menghasilkan kegagalan, sehingga akan mempengaruhi keberhasilan dan kemajuan pegawai serta menumbuhkan perilaku yang deskriptif lainnya.

Disiplin kerja adalah suatu kondisi dimana penyelenggara pendidikan menggunakan waktu mereka dalam cara-cara penyelenggaraan pendidikan, dimana yang tidak dapat membuat kondisi ini maka dapat menjadi penyelenggara pendidikan yang akhirnya akan menghasilkan kegagalan. Sementara itu fungsi disiplin penyelenggara pendidikan menghendaki agar mengontrol tingkah laku yang menyimpang dengan menggunakan hukuman dan hadiah. Hukuman menunjukan kepada suatu perangsang yang ingin dihindari atau berusaha melarikan diri. Kombinasi hukuman dan hadiah yang mendalam sebagai teknik disiplin disebut restitusi (penggantian kerugian). Dalam psikologi Amerika kata "Hukuman" tak terkenal, namun bukti eksperimen menunjukkan bahwa ia merupakan alat yang efektif dan merupakan alat kontrol yang impulsif.

Disiplin disini merupakan hal yang dipaksakan oleh Kepala sekolah atau bukan merupakan disiplin pribadi tapi karena adanya pengawasan dari Kepala sekolah. Selain pengawasan Kepala sekolah, pengawasan bisa saja dari kelompoknya. Dan biasanya disiplin ini terjadi karena adanya tugas. Kedisiplinan merupakan sikap mental dari seseorang atau kelompok yang senantiasa berkehendak untuk mengikuti atau mematuhi segala peraturan yang ditentukan. Kedisiplinan mencerminkan kekuatan. Maksudnya adalah bahwa seseorang yang sehat dan kuat biasanya mempunyai disiplin yang baik. Ia mempunyai keteraturan didalam menjaga dirinya teratur makan, tertib tidur atau istirahat, tertib dan olah raga, tertib menjaga kesehatan dan lain sebagainya. Dengan demikian, ciri utama dari disiplin adalah adanya keteraturan dan ketertiban.

Dari beberapa defenisi tentang disiplin yang telah dipaparkan dimuka, persamaan-persamaan yang dapat diambil adalah: (1) Disiplin mencerminkan dua dimensi yaitu dimensi internal dan dimensi eksternal peserta diklat karena tidak terpenuhi kebutuhan-kebutuhannya. (2) Disiplin dapat dikelompokkan kedalam 
disiplin belajar dalam kelas dan belajar diluar kelas. (3) Disiplin dapat juga dikelompokkan kedalam disiplin positif dan disiplin negativ. (4) Disiplin dalam organisasi pada dasarnya sama dengan disiplin di diklat, yaitu adanya standarisasi atau peraturan yang harus ditaati peserta diklat.

\section{Kerangka Bepikir}

Pendidikan mempunyai tugas membina, mengkoordinasi, mempersiapkan dan menyelenggarakaan pendidikan, pelatihan, dan penataran dalam melaksanakan tugasnya antara lain: (1) Penyusunan program, persiapan tenaga pengajar, dan pengembangan materi pendidikan; (2) Penyelenggaraan pendidikan, pelatihan dan penataran; (3) Pengolahan data, penelaahan serta penyusunan laporan pelaksanaan pendidikan, pelatihan, dan penataan.

Kedisiplinan diartikan sebagai upaya untuk mencegah terjadinya pelanggaran - pelanggaran terhadap ketentuan - ketentuan yang telah disepakati bersama dalam melaksanakan kegiatan pengajaran, agar pemberian sanksi pada seseorang atau kelompok dosen dapat dihindari. Bahwa kedisiplinan guru mempunyai hubungan dengan kinerja guru. Untuk itu, diduga terdapat korelasi positip antara kedisiplinan dengan kinerja guru.

Kedisiplinan mempunyai beberapa indikator atau unsur yang mendukung, serta mempunyai peranan besar bagi keberhasilan seorang guru. Beberapa indikator kedisiplinan guru meliputi: (1) patuh dan taat pada ketentuan - ketentuan yang telah disepakati bersama (2) kemampuan mengendalikan diri (3) patuh terhadap tugas pokok guru (4) menciptakan suasana harmonis terhadap rekan kerja dan atasan (5) memiliki sikap kreatif dan inovasi (6) memiliki loyalitas terhadap profesinya.

Kinerja guru merupakan ukuran hubungan antara input (Tenaga kerja, modal, sumberdaya alam, energi dan lain - lain) dengan kualitas dan kuantitas output (barang dan jasa).

\section{HASIL PEMBAHASAN}

Menurut Arikunto dalam bukunya Prosedur penelitian suatu pendekatan praktek menyatakan bahwa, apabila subjeknya kurang dari 100 pengambilan sampel harus dilakukan semua sehingga mewakili penelitian populasi sedangkan jika jumlah subjek besar dapat diambil antara 10 - $15 \%$ dengan memperhatikan: kemampuan peniliti dilihat dari waktu, tenaga dan dana. Berdasarkan hal tersebut, subjek populasi dalam penelitian ini adalah semua guru dan pegawai staf tata usaha SD Negeri 007 Teluk Sebong, sedangkan populasi yang diambil dari siswa $10 \%$ dari jumlah 304 siswa sejumlah 30 siswa. Instrumen penelitian berupa qouisioner dibagikan kepada siswa dan guru serta staf tata usaha. Dari hasil diperoleh ternyata quisioner yang berasal dari siswa ditemukan hasil yang kurang memuaskan sedangkan qouisioner dari guru dan staf tata usaha menunjukkan hasil yang cukup memuaskan. Hal ini terdapat perbedaan yang cukup signifikan antara siswa, guru dan staf tata usaha.

Oleh karena itu peneliti menemukan adanya kesenjangan pada guru dan staf tata usaha dalam hal kedisiplinan. Untuk itu penulis melakukan beberapa tindakan agar kedisiplinan guru dan tenaga kependidikan dapat terlaksana dengan baik diantaranya: (1) Melakukan pendekatan kepada guru dalam upaya perubahan sikap dan prilaku disiplin guru; (2) Mengamati perubahan sikap dan prilaku guru dan staf tata usaha.; (3) Menyebarkan qouisioner/ angket hanya kepada siswa untuk melihat sejauh mana perubahan sikap dan prilaku disiplin guru dan staf tata usaha dalam peningkatan kinerja.

Setelah penulis melaksanakan segala tindakan yang korektif, tindakan-tindakan dalam rangka disiplin perlu diterima sebagai usaha memenuhi tujuan yang telah ditetapkan bersamasama. Penulis akan menjabarkan hasil kuisioner yang diisi oleh seluruh guru dan staf tata usaha serta 30 orang siswa yang terdiri dari kelas $\mathrm{V}$, dan kelas VI, (10 orang siswa laki-laki dan 11 orang siswa perempuan), $10 \%$ dari 304 jumlah siswa di SD Negeri 007 Teluk Sebong.

Berdasarkan hasil dari indikator-indikator yang disebarkan melalui qouisioner pertama pada siswa dapat disimpulkan bahwa kedisiplinan guru dalam upaya meningkatkan kinerja guru ternyata hasilnya kurang memuaskan terhadap kinerja guru. Pada dasarnya disiplin merupakan pedoman atau landasan dalam menciptakan suatu suasana tertib dan teratur yang sangat dibutuhkan dalam suatu organisasi agar guru dan pegawai dapat bekerja dengan baik, teratur dan bergairah. Oleh karena itu disiplin tidak boleh dilanggar baik dari segi ucapan, perbuatan, maupun tulisan. Dari hasil diatas maka dilakukan tindakan lanjutan sebagai berikut : (1) Pendekatan secara individu dan kelompok untuk dapat melaksanakan perannya 
lebih baik,berusaha menciptakan budaya disiplin dalam kondisi tenang (damai), dan kepatuhan internal dalam diri seseorang yang merupakan bagian dari kelumpok itu sendiri, untuk menghalangi para pegawai yang lain melakukan tindakan-tindakan yang serupa (melanggara disiplin ), dan untuk menjaga berbagai standar kelompok tetap konsisten dan efektif; (2) Melakukan pembinaan berupa teguran dan peringatan, agar dapat berperilaku efektif, efisien dan profesional dalam rangka menjunjung tinggi integritas kehormatan dan identitas guru. Teguran tersebut untuk menumbuhkembangkan rasa kesadaran yang tinggi terhadap kebutuhan/ dorongan/ motif yang ada dalam diri seseorang untuk berbuat mengikuti aturan/ norma vang berlaku dalam lingkungan kerja. Teguri uga sebagai tindakan korektif untuk rıcnangani pelanggaran -pelanggaran lebih lanjut. Kegiatan korektif ini sering berupa suatu bentuk hukuman dan disebut tindakan pendisiplinan, tujuannya untuk memperlemah perilaku dan cenderung untuk mengurangi frekwensi perilaku yang berikutnya dan biasanya terdiri dari permintaan suatu konsekuensi yang tidak diharapkan, ada beberapa contoh konsekuensi yang dapat membantu untuk menentukan apakah stimulus dapat efektif dalam mengurangi perilaku yang tidak diinginkan yaitu peringatan lisan, teguran keras, meningkatkan pengawasan, mengurangi pujian, peringatan tertulis, tidak memperoleh penghargaan, pengurangan tanggungjawab, pergantian posisi jabatan. (3) Pemberian penghargaan dan motivasi bagi guru dan staff tata usaha, bahwa yang dilakukan dihargai dan memiliki nilai yang sangat tinggi, serta sebagai perbuatan amal ibadah baik untuk dunia maupun diakhirat kelak.

Dari kenyataan diatas untuk mengetahui keberhasilan kepala sekolah terhadap perubahan yang dilakukan, maka qouisioner lanjutan disebarkan kepada

siswa untuk mengukur sejauhmana perubahan yang sudah dilakukan oleh guru dan staff tata usaha. Ternyata dari qouisioner lanjutan yang disebarkan kepada siswa diperoleh hasilnya bahwa disiplin guru terdapat perubahan kearah yang lebih baik, hal ini dapat dilihat dari hasil qouisioner yang ke dua, seperti pada tabel diatas siklus kedua, dapat ditarik kesimpulan bahwa dengan sejumlah tindakan yang dilakukan oleh kepala sekolah dapat secara nyata mempengaruhi seluruh iklim organisasi dan etos kerja, secara khusus dapat mengimplentasikan disiplin kerja sebagai kepuasan kerja guru dan staff tata usaha di SD Negeri 007 Teluk Sebong Kecamatan Teluk Sebong Kabupaten Bintan.

\section{SIMPULAN DAN SARAN Simpulan}

Berdasarkan uraian yang telah penulis paparkan pada analisa kedisiplinan guru dalam upaya meningkatkan kinerja guru pada SD Negeri 007 Teluk Sebong. maka dapat disimpulkan, sebagai berikut: (1) Patuh dan taat pada ketentuan bersama yang meliputi: datang tepat pada waktunya, mengikuti kegiatankegiatan sekolah dll, melaksanakan pembelajaran tepat waktu, mengunakan pakaian dan atribut sesuai ketentuan yang berlaku, dan guru menyusun perangkat tepat pada waktunya; (2) Kemampuan mengendalikan diri yang meliputi: guru dalam menjalankan tugas selalu mengedepankan etika; (3) Patuh terhadap tugas pokok guru yang meliputi: guru menyusun perangkat kerja, menyiapkan media pembelajaran, melakukan evaluasi dan pengayaan, serta memberikan penilaian sikap dan perilaku terhadap siswa; (4) Menciptakan suasana harmonis terhadap rekan kerja dan atasan yang meliputi: guru memiliki rasa empati terhadap rekan kerja didalam maupun diluar lingkungan kerja, guru menyelesaikan persoalan secara demokrasi dan kekeluargaan; (5) Menciptakan sikap kreatif dan inovasi yang meliputi: Guru memahami IT, memiliki wawasan kekinian, memiliki sikap tanggap lingkungan, dan mengikuti pelatihan penyetaraan profesi; (6) Memiliki loyalitas terhadap profesinya yang meliputi: Guru memiliki perasaan positif terhadap pekerjaanya, memiliki antusiasme yang tinggi tentang waktu kerja tidak terasa berakhir, memiliki peluang meraih prestasi dan mempersiapkan masa depan yang mendukung profesinya, serta memberi teguran dan sanksi terhadap guru yang melalaikan tugas dan tanggungjawab keprofesiannya.

\section{Saran}

Berdasarkan kesimpulan sebagai hasil dari penulisan makalah ini dapat dikemukakan beberapa saran: (1) Kedisiplinan guru dalam upaya meningkatkan kinerja guru perlu ditumbuhkan, ditanamkan dan dipertahankan sejak dini, karena disiplin memiliki peran yang sangat penting dalam menunjang keberhasilan pada diri sendiri, kelompok, organisasi dimana kita menjalankan tugas, karena disiplin 
merupakan salah satu nusur untuk mencapai kesuksesan dimasa depan; (2) Demikian juga dengan disiplin siswa dimana peran pendidik dan tenaga kependidikan diharapkan menjadi contoh dan tauladan bagi siswa karena disiplin dalam bebagai kegiatan dapat meningkatkan sumber daya menusia yang memiliki kualitas kepribadian keterampilan, kemandirian yang berdasarkan imtag dan berilmu pengetahuan, maka perlu disiplin ditingkatkan, sehingga tujuan pendidikan dapat terwujud dengan baik sebagaimana yang diharapkan sekolah.

\section{DAFTAR PUSTAKA}

Abd. Rahman Abror. 1993. Psikologi Pendidikan. Yogyakarta: Tiara Wacana.

Charles Horton Cooley. Soscial Organization. File: III C-III Tempolchb. Htm Chapter 6. Koestoer P. 1993. Dinamika Dalam Psikologi Pendidikan. Jakarta: Erlangga.

Keit Davis \& John W Newstrom. 1996. Prilaku Dalam Organisasi. Jakarta: Erlangga.

Lee J. Cronbach. 1954. Educational Phsycology. New York: Harcourt, Brace \& Wortd, Inch.

Made Pidarta. 1995. Peranan Kepala Sekolah Pada Pendidikan Dasar. Jakarta: Gramedia.
Oemar Hamalik. 2000. Psikologi Belajar dan Mengajar. Bandung: Sinar Baru Algensindo.

Oteng Sutisna. 1987. Administrasi Pendidikan Dasar Teoritis Untuk Praktek Profesional. Bandung: Angkasa.

Rudolf Dreikurrs \& Pearl Cassel. 1984. Disiplin Tanpa Hukuman. Bandung: Remaja Karya.

Ricard M. Sters. 1994. Efektivitas Organisasi. Jakarta: Erlangga.

Reksohadiprodjo, Sukanto dan T. Hani Handoko. 1994. Organisasi Perusahaan Teori. Jakarta: Erlangga.

Reksohadiprodjo, Sukanto dan T. Hani Handoko. 1994. Organisasi Perusahaan Teori. Jakarta: Erlangga.

Sudjana, Nana. 1989 .Teori-teori untuk pengajaran. Jakarta: Lembaga Penerbit Fakultas Ekonomi UI.

Sutarto. 1995. Dasar-dasar Organisasi. Yogyakarta: Gajah Mada University Press.

Stephen P. Robin. 1986. Organization Behavior. New Jersey: Printice Hall Clif.

Soegeng Prijodarminto. 1994. Disiplin Kiat Menuju Sukses. Jakarta: Abadi. 